\title{
PROBLEMATIKA PEMBENTUKAN REGULASI PEMILU DALAM MEWUJUDKAN PEMILU SERENTAK YANG DEMOKRATIS
}

\author{
ZENNIS HELEN \\ Fakultas Hukum Universitas Ekasakti Padang \\ zennishelen78@gmail.com
}

\begin{abstract}
Election is a means of exercising people's sovereignty. Election regulations continue to change every time an election is held. So that there is no permanent and long-term election regulation. The 2019 simultaneous elections which were regulated by Law No.7 of 2017 concerning General Elections would not last for a period of five years. This is because the DPR and the President are currently forming a new Election Bill which is being discussed between Commission II of the DPR and the government. In Law No.7 of 2017 concerning General Elections, several laws have been codified, namely the Law on Election Implementation, the Law on Legislative Elections, and the Law on Presidential and Vice-Presidential Elections, several separate laws then become one in Law No.7 of the year. 2017 concerning General Election. This is what is called the codification of elections, namely the compliance of laws and regulations relating to elections. When the formation of the Election Bill, there was also a very sharp intersection of interests between political parties, especially those discussing the parliamentary threshold, the electoral system, the threshold for presidential and vice presidential candidates. Because the Election Law is drafted within a period of five years, ideally the Election Law contains very technical and very detailed matters. It is intended that election regulations in the form of regulations at the General Election Commission (KPU) level and Election Supervisory Body Regulations (Bawaslu) can be reduced because at the level of the Law itself, technical regulations are already regulated. This is because too many regulations at the PKPU and Perbawaslu levels will make it difficult for election organizers in provinces, districts / cities, especially when PKPU tends to undergo changes because they have to consult with the DPR. This does not mean that PKPU and Perbawaslu are unnecessary but reduced so that election regulations are not obese. And the enforcement of election law, both administrative disputes, process and criminal law enforcement, must contain the principle of equality of the parties to the dispute. It is prohibited to enforce one-sided election law, selective cutting and so on.
\end{abstract}

Keywords: Problematic, Formation, Regulation, Election, Inside, Creating, Election, Simultaneous, Yang, Democratic.

\begin{abstract}
Abstrak: Pemilu merupakan sarana pelaksanaan kedaulatan rakyat. Regulasi pemilu terus mengalami perubahan tiap pemilu digelar. Sehingga tak ada regulasi Pemilu yang parmanen dan berjangka panjang. Pemilu serentak 2019 yang lalu diatur dengan UU No 7 Tahun 2017 tentang Pemilihan Umum, tidak akan bertahan untuk jangka waktu lima tahun. Sebab, DPR dan Presiden kini tengah membentuk RUU Pemilu baru yang tengah dibahas antara Komisi II DPR dengan pemerintah. Dalam UU No 7 Tahun 2017 tentang Pemilihan Umum, telah terjadi kodifikasi beberapa undang-undang, yakni Undang-Undang Penyelenggaraan pemilu, UU Pemilihan Legislatif, dan UU Pemilihan Presiden dan Wakil Presiden, beberapa UU yang terpisah itu kemudian menjadi satu dalam UU No 7 Tahun 2017 tentang Pemilihan Umum. Inilah yang


disebut dengan kodifikasi pemilu, yakni pengitaban peraturan perundang-undangan yang berkaitan dengan pemilu. Ketika Pembentukan RUU Pemilu ini pun menimbulkan persilangan kepentingan antar partai politik yang sangat tajam, terutama yang membahas soal ambang batas parlemen, sistem pemilu, ambang batas calon presiden dan wakil presiden. Karena UU Pemilu dibuat dalam jangka waktu lima tahun, sehingga idealnya UU Pemilu itu memuat hal-hal yang sangat teknis dan sangat detail. Itu bertujuan agar regulasi pemilu dalam bentuk peraturan di tingkat Komisi Pemilihan Umum (KPU) dan Peraturan Badan Pengawas Pemilu (Bawaslu) dapat dikurangi karena di tingkat Undang-Undang sendiri sudah diatur regulasi yang bersifat teknis. Sebab, dengan terlalu banyaknya regulasi di tingkat PKPU dan Perbawaslu akan menyulitkan penyelenggara pemilu di provinsi, kabupaten/kota apalagi PKPU cenderung mengalami perubahan karena harus berkonsultasi dengan DPR. Bukan berarti PKPU dan Perbawaslu tidak diperlukan namun dikurangi sehingga regulasi pemilu tak mengalami obesitas. Dan penegakan hukum pemilu pun baik sengketa administrasi, proses maupun penegakan hukum pidananya harus mengandung asas kesetaraan para pihak pada dalam sengketa itu. Tidak boleh penegakan hukum pemilu yang berat sebelah, tebang pilih dan sebagainya.

Kata Kunci: Problematika, Pembentukan, Regulasi, Pemilu, Dalam, Mewujudkan, Pemilu, Serentak, Yang, Demokratis.

\section{A. Pendahuluan}

Pemilihan Umum (Pemilu) adalah sarana bagi rakyat untuk melaksanakan kedaulatannya. Menurut Pasal 1 Ayat (2) UUD NRI Tahun 1945" Kedaulatan berada ditangan rakyat dan dilaksanakan menurut Undang-Undang Dasar. Salah satu instrumen untuk melaksanakan kedaulatan rakyat itu adalah melalui Pemilu yang digelar secara langsung, umum, bebas, rahasia (luber) da ujur dan adil. Negara Indonesia adalah negara yang menganut sistem hukum kontinental. Sistem ini mengutamakan hukum tertulis yang berupa peraturan perundang-undangan yang merupakan produk legislasi sebagai sendi utama sistem hukumnya. (Al Atok 2015,1). Karena itu, negara-negara yang berada dalam sistem hukum kontinental selalu berusaha menyusun hukum-hukumnya dalam bentuk tertulis dalam suatu sistematika yag diupayakan selengkap mungkin dalam sebuah kitab undang-undang (kodifikasi). (Al Atok, 2015, Ibid). Pemilu sebagai sebuah agenda demokrasi elektoral yang digelar rutin sekali dalam lima tahun maka pelaksanaannya harus dibentuk dalam UndangUndang. Untuk pemilu yang digelar serentak 2019 maka menggunakan UU No 7 Tahun 2017 Tentang Pemilihan Umum.

Tak hanya itu, pemilu juga merupakan sarana penyaluran hak rakyat dalam bernegara. Kedaulatan yang ada di tangan rakyat itu dilimpahkan kepada orang yang dipercaya dan mampu memimpin dan memperjuangkan kepentingan rakyat. Karena itu, terjaminnya hak suara rakyat harus menjadi kewajiban jajaran penyelenggara pemilu (A. Afifuddin, Menjaga Hak Pilih Warga, Republika, 28 Juli 2018). Pembentukan regulasi pemilu yang baik merupakan separoh dari kesuksesan pemilu serentak 2019. Saat ini, paradigma pembentukan peraturan perundang-undangan, khususnya UU Pemilu sudah mengalami kodifikasi. Pemerintahan Joko Widodo (2019-2024) yang telah dilantik pada 20 Oktober 2019 yang lalu, adalah produk peraturan perundangundangan yang dikodifikasi (dikitabkan) itu. Yang pada mulanya tersebar ke pelbagai peraturan perundang-undangan, yakni UU No 42 Tahun 2008 tentang Pemilihan Umum Presiden dan Wakil Presiden (Pilpres), UU No 15 Tahun 2011 tentang Penyelenggara Pemilihan Umum dan UU No 8 Tahun 2012 tentang Pemilihan Umum E-ISSN: 2657-0300 Lembaga Penelitian dan Penerbitan Hasil Penelitian Ensiklopedia 209 
Anggota DPR, DPD, dan DPRD, pada pemilu serentak 2019 lalu, disatukan ke dalam UU No 7 Tahun 2017 tentang Pemilihan Umum yang sering juga disebut dengan pemilu serentak lima kotak.

Pengitaban ke dalam satu UU, yakni UU No 7 Tahun 2017 tentang Pemilu merupakan langkah maju dalam pembentukan peraturan perundang-undangan tentang Pemilu dan memudahkan penyelenggara pemilu dalam mencari dan memahami sebuah Undang-undang. Kalau-lah Undang-Undang No 2 Tahun 2008 tentang Partai Politik dan UU No 10 Tahun 2016 tentang Pemilihan Kepala Daerah (Pilkada) dapat satukan ke dalam UU No 7 Tahun 2017 tentang Pemilu maka regulasi pemilu serentak 2019 akan bertambah baik lagi. Namun, kedua regulasi itu belum dimasukkan ke dalam UU No 7 Tahun 2017.

Pembentukan peraturan perundang-undangan, khususnya regulasi pemilu di Indonesia sudah mulai melangkah ke arah kodifikasi peraturan perundagan-undangan. Dalam hal ini penulis sebut juga dengan istilah peraturan perundang-undangan yang bersifat tertulis dan terkodifikasi (dikitabkan atau dibukukan), disamping itu tidak sedikit pula yang masih tersebar ke dalam pelbagai peraturan peraturan perundangundangan. Revisi UU No 7 Tahun 2017 yang telah direncanakan DPR periode 20192024 maka UU Parpol dan UU Pilkada agar ke depannya disatukan ke dalam UU Pemilu.

Ini berarti, era kebutuhan hukum saat ini, sudah mulai bergeser ke arah kodifikasi dan telah menjelajah ke dunia kepemiluan di Indonesia. Hal ini dapat kita lihat dalam pembentukan regulasi pemilihan umum (Pemilu) yang dilaksanakan secara serentak di seluruh Indonesia yang sekali lagi telah dikukuhkan dalam UU No 7 Tahun 2017 tentang Pemilihan Umum (Pemilu), yang diundangkan di Jakarta pada tanggal 16 Agustus 2017 dalam Lembaran Negara Republik Indonesia Tahun 2017 Nomor 182, dan terdiri dari 573 pasal. Pengkodifikasian tiga jenis peraturan perundang-undangan tentang Pemilihan Umum ini ke dalam satu undang-undang, bertujuan untuk merampingkan regulasi pemilu agar tidak mengalami obesitas (kegemukan) dan menyederhanakan pemilu sehingga lebih mudah, tak rumit, tak berbelit, memudahkan pemilih menggunakan hak pilihnya, dan tingkat partisipasi pemilih di bilik suara mengalami peningkatan setiap pemilu.

Perubahan paradigma pembentukan peraturan perundang-undangan (baca: regulasi pemilu) disebabkan oleh perubahan hukum dasar sebagaimana yang dijelaskan Susi Dwi Harijanti, ia mengatakan rangkaian perubahan yang terjadi selama kurun waktu 1999-2002 yang memperlihatkan perubahan mendasar materi muatan yang terdapat dalam UUD 1945, yang secara umum perubahan itu salah satunya adalah meliputi perubahan paradigma (Susi Dwi Harijanti, 2017" Sistem Ketatanegaraan Berdasarkan UUD 1945" Makalah yang dipresentasikan dalam Acara Bimbingan Teknis Hukum Acara Mahkamah Konstitusi Bagi Dosen dan Staf Pengajar APPTHI di Cisarua Bogor 16 s/d 20 Juli 2017). Dalam pandangan penulis, perubahan paradigma perubahan konstitusi inilah yang menular ke dalam pembentukan peraturan perundang-undangan yang berada dibawahnya (baca: Undang-undang).

\section{B. Metodologi Penelitian}

Berdasarkan latar belakang diatas, maka hendak disusun ke dalam jurnal dalam bentuk tiga pertanyaan penting. Pertama, bagaimana proses penyusunan maupun substansi UU No 7 Tahun 2017 tentang Pemilihan Umum? Kedua, bagaimana 
problematika penyusunan peraturan Komisi Pemilihan Umum (KPU) Nomor 20 Tahun 2018 tentang Pencalonan Anggota DPR dan DPRD? Ketiga, Bagaimana problematika penegakan hukum pemilu (Pelanggaran, sengketa, dan PHPU)? Dengan menggunakan metodologi penelitian yuridis normatif.

\section{Hasil dan Pembahasan}

\section{Proses Penyusunan maupun substansi UU No 7 Tahun 2017 tentang Pemilihan Umum}

Pemilu merupakan suatu proses menentukan pilihan terhadap pemimpin atau wakil rakyat yang dilakukan oleh seluruh rakyat/pemilih sepanjang memenuhi persyaratan berdasarkan ketentuan peraturan perundang-undangan yang berlaku. Pemilu merupakan awal dari keikutsertaan rakyat dalam proses pengambilan keputusan dengan jalan memberikan suara kepada siapa yang mewakili mereka dalam lembaga perwakilan (Thaib 2016,40). Melalui pemilu rakyat memunculkan para calon pemimpin dan menyaring calon-calon tersebut berdasarkan nilai yang berlaku. Keikutsertaan rakyat dalam pemilu, dapat juga dipandang sebagai wujud dalam proses pemerintahan, sebab melalui lembaga pemilu, masyarakat ikut menentukan kebijaksanaan dasar yang akan dilaksanakan pemimpin terpilih (Hasanah 2016,41).

Dasar konstitusional Pemilihan Umum diatur dalam Pasal 22E Ayat (1), Ayat (2), Ayat (3), Ayat (4), Ayat (5), Ayat (6) Undang -Undang Dasar Negara Republik Indonesia (UUD NRI Tahun 1945). Pada Ayat (5) berbunyi “ Ketentuan lebih lanjut tentang Pemilihan Umum dengan Undang-undang. Berdasarkan perintah pasal inilah UU No 7 Tahun 2017 Tentang Pemilihan Umum dibentuk DPR dan Presiden serta ini pulalah yang menjadi kerangka hukum dan yuridis pelaksanaan pemilu serentak yang digelar pada 17 April 2019 lalu untuk memilih anggota Dewan Perwakilan Rakyat, anggota Dewan Perwakilan Daerah, Presiden dan Wakil Presiden, anggota Dewan Perwakilan Rakyat Daerah.

Dalam UU No 7 Tahun 2017, sistem pemilu Indonesia mengalami perubahan yang cukup signifikan dimana Pemilu dilangsungkan selama 5 (lima) tahun sekali untuk memilih Presiden dan Wakil Presiden serta anggota DPR, DPD, DPRD Provinsi, dan DPRD Kabupaten/kota. Pemilu secara langsung bukan hanya dilakukan untuk memilih Presiden, dan Anggota Legislatif saja, tetapi pemilu langsung juga berlaku bagi pemilihan kepala daerah (Siregar 2018,V). Dalam konteks pelaksanaan pemilihan umum di Indonesia digelar secara serentak dengan pemilu lima kotak. Undang-Undang No 7 Tahun 2017 tentang Pemilihan Umum itu diinisiasi oleh Presiden Republik Indonesia Joko Widodo dan ia mengirimkan surat presiden (surpres) kepada pimpinan DPR yang didalam surat itu juga memuat menteri yang mewakili Presiden dalam melakukan pembahasan RUU bersama DPR. DPR mulai membahas RUU dari Presiden dalam jangka waktu paling lama 60 (enam puluh) hari terhitung sejak surat presiden diterima. Untuk keperluan pembahasan RUU di DPR, menteri atau pimpinan lembaga pemrakarsa memperbanyak naskah RUU tersebut dalam jumlah yang diperlukan.

Proses pembentukan peraturan perundang-undangan di Indonesia diatur dalam UU No 12 Tahun 2011 tentang Pembentukan Peraturan Perundang-undangan, yang dimulai dari tahapan perencanaan, penyusunan, pembahasan, pengesahan atau penetapan, dan pengundangan. Dalam pembentukan UU No 7 Tahun 2017 tentang Pemilihan Umum ini pun mengacu kepada UU a quo, yakni melalui proses pembahasan di DPR bersama dengan pemerintah yang sebelumnya telah dimasukkan 
dalam program legislasi nasional (prolegnas) 2017, dan kemudian dibahas dengan DPR.

Untuk memudahkan pembahasan, DPR membentuk Panitia Khusus (Pansus) RUU Pemilu yang diketuai Lukman Edi (Fraksi PKB), dan di pihak pemerintah diwakili oleh Menteri Dalam Negeri Tjahyo Kumolo. Pihak-pihak inilah yang secara kontinue melakukan pembahasan RUU Pemilu dengan pemerintah. Dalam pembahasan, setidaknya, tercatat 2.885 masalah dalam daftar Inventaris masalah(DIM) yang merupakan sikap sepuluh fraksi di DPR. Mengingat banyaknya permasalahan yang disuarakan fraksi-fraksi, sudah dapat ditebak akan muncul sejumlah perbedaan pandangan dalam pembahasannya, baik itu di internal DPR maupun dengan pemerintah. Namun, ada beberapa isu krusial yang menjadi bahan perdebatan alot dalam pembahasannya, yakni menyangkut pengunaan sistem pemilu daftar terbuka atau kembali tertutup, seperti pemilu-pemilu Orde Baru (sistem pemilu legislatif), soal ambang batas parlemen, syarat parpol dalam pencalonan presiden (ambang batas pencapresan), alokasi kursi di daerah pemilihan, juga soal metode konversi suara menjadi kursi. https://republika.co.id/berita/koran/newsupdate/17/01/26/okdcg620waktu-dan-isu-krusial-ruu-pemilu, diakses pada Kamis, 10 Oktober 2019,pukul 07.00 WIB.

Menyangkut dengan sistem pemilu legislatif, setidaknya ada dua pilihan sistem yang mengapung dan dibahas secara alot di DPR, yakni sistem pemilu proporsional terbuka dan sistem pemilu proporsional tertutup. Beberapa fraksi berbeda pandangan tentang ini. PDI dan Golkar lebih cenderung mengalihkan sistem pemilu dari proporsional terbuka dan sistem prporsional tertutup (https://republika.co.id/berita/koran/newsupdate/17/01/26/okdc 620-waktu-dan-isukrusial-ruu-pemilu, diakses pada Kamis, 10 Oktober 2019,pukul 07.00 WIB) Sementara, PPP, PAN, Nasdem, Hanura, PKS dan Demokrat lebih memilih sistem proporsional

terbuka.https://republika.co.id/berita/koran/newsupdate/17/01/26/okdcg620-waktudan-isu-krusial-ruu-pemilu, diakses pada Kamis, 10 Oktober 2019,pukul 07.00 WIB). Undang-undang adalah produk politik, UU ini sangat seksi sekali karena berujung pada kekuasaan. Ada pertarungan politik yang sangat besar dalam pembentukannya, antara partai besar dengan partai kecil. Jika kesepakatan tidak tercapai maka pengambilan keputusan dilakukan dengan voting.

Mekanisme voting jelas hanya akan menguntungkan partai yang jumlah kursi banyak, sehingga kepentingan merekalah sesungguhnya yang banyak diakomodir dalam RUU Pemilu itu. Ini mengambarkan bahwa hukum adalah produk politik sebab ia merupakan kristalisasi, formalisasi atau legalisasi dari kehendak-kehendak politik yang saling bersaingan baik melalui kompromi politik maupun melalui dominasi oleh kekuatan politik yang terbesar. (MD Mahfud M 2009,5).

Beberapa isu krusial yang ditujukan untuk perbaikan pemilu di masa mendatang, misalnya tentang perbaikan sistem pemilu yang relevan dengan sistem kepartaian dan sistem pemerintahan presidensial, mengefektifkan hak pilih, dan pengaturan persyaratan pencalonan anggota legislatif dan tentang pengaturan politik uang dapat dikurangi dan sanksi yang tepat secara hukum, tidak pernah dibahas lebih dalam, detail dan serius. Itu disebabkan karena keempat hal ini tidak berujung pada kekuasaan. Membahasnya dinilai membuang waktu. Padahal, ini sangat menentukan bagi kualitas caleg terpilih. 
Adapun yang dibahas detail dan serius adalah tentang besaran daerah pemilihan (dapil) karena akan berujung pada perolehan jumlah kursi di parlemen, dan ambang batas parlemen yang mengalami kenaikan untuk pemilu 2019, dipatok pada angka 4\% dengan tujuan untuk penyederhanaan parpol, akan tetapi parpol tidak juga dapat disederhanakan justru yang terjadi sebaliknya, yakni jumlah parpol tetap mengalami pertambahan pada pelaksanaan pemilu 2019 lalu.

Ambang batas presidensial itu menyebabkan setiap parpol tidak dapat mengajukan calon presiden dan ia harus berkoalisi dengan parpol lain. Ambang batas ini telah menyebabkan calon Presiden dan Wakil Presiden hanya dua pasang calon yang berlaga dalam pemilu 2019, yakni Joko Widodo- Ma,ruf Amin dan Prabowo Subianto- Sandiaga Salahuddin Uno. Jika hal ini tidak dikelola dengan baik oleh pemangku kepentingan yang terkait dengan pemilu, diyakini dapat memperparah kerusakan kohesi social di tengah masyarakat kita. Kondisi ini penulis sebut dengan titik kritis kohesi social dan menyebabkan partai politik baik ditingkat nasional maupun daerah berada pada dua arus kekuatan besar, yakni pendukung Jokowi- Ma,ruf dan Prabowo-Sandi. (Zennis Helen, Titik Kritis Kohesi Sosial, Republika, 29 Oktober 2018, hal.6).

\section{Problema Penyusunan Peraturan KPU Nomor 20 Tahun 2018 Tentang Pencalonan Anggota DPR dan DPRD}

Undang-Undang No 7 Tahun 2017 yang menjadi dasar hukum pelaksanaan pemilu serentak 2019 dan mengatur hal-hal yang umum harus dioperasionalkan lagi melalui Peraturan Komisi Pemilihan Umum (PKPU) yang dibuat oleh KPU RI dan mengikat pada KPU Propinsi dan KPU Kabupaten/Kota. Misalnya, Peraturan Komisi Pemilihan Umum (PKPU) tentang Jadwal dan Tahapan Penyelenggaraan Pemilihan Umum, Peraturan Komisi Pemilihan Umum tentang verifikasi partai politik, Peraturan Komisi Pemilihan Umum Tentang Pencalonan Anggota DPR dan DPRD, dan Peraturan Komisi Pemilihan Umum tentang Pencalonan Anggota Dewan Perwakilan Daerah (DPD). Aneka peraturan ini mengatur hal-hal yang operasional dan rinci mengenai pemilu untuk memilih anggota DPR, DPD, DPRD dan Presiden dan Wakil Presiden.

Peraturan KPU dalam proses penyelenggaraan pemilu sederajat dengan Peraturan Pemerintah (PP) dan sebagai pengganti PP dalam pengaturan teknis operasional pemilu adalah Peraturan Komisi Pemilihan Umum (PKPU) yang dibuat sebagai peraturan pelaksana pemilu yang mempunyai kelebihan dibanding dengan PP, yakni PKPU harus melewati uji public dan dikonsultasikan dengan DPR. Dalam makalah ini hendak difokuskan kepada Peraturan Komisi Pemilihan Umum (PKPU) No 20 Tahun 2018 tentang Pencalonan Anggota DPR dan DPRD. PKPU ini adalah instrumen untuk menterjemahkan Pasal 240 Ayat (1) UU No 7 Tahun 2017 yang mengatur tentang Persyaratan Bakal Calon Anggota DPR, DPRD Provinsi dan DPRD Kabupaten/Kota. Penyelenggara pemilu tidak tunduk pada undang-undang itu. Ia dinilai melakukan akrobat hukum dengan mengelaborasi ketentuan ini dengan menambah tiga persyaratan bakal calon anggota legislatif, yakni tidak pernah menjadi narapidana tindak pidana narkotika, kekerasan seksual terhadap anak, dan tindak pidana korupsi.

Padahal, Pasal 242 Ayat (1) huruf g UU a quo hanya menyebutkan bahwa “ Bakal calon anggota DPR, DPRD Provinsi, DPRD Kabupaten/kota adalah warga Negara Indonesia dan harus memenuhi persyaratan tidak pernah dipidana penjara berdasarkan putusan pengadilan yang telah memperoleh kekuatan hukum tetap karena melakukan tindak pidana yang diancam dengan pidana penjara 5 (lima) tahun atau E-ISSN: 2657-0300 Lembaga Penelitian dan Penerbitan Hasil Penelitian Ensiklopedia 213 
lebih, kecuali secara terbuka dan jujur mengemukakan kepada public bahwa yang bersangkutan mantan terpidana". Karena KPU dinilai oleh parpol menambah persyaratan selain yang disebutkan diatas maka hal inilah yang memunculkan perlawanan parpol, sehingga berujung ke Mahkamah Agung dan akhirnya dibatalkan Mahkamah Agung.

Salah satu alasan parpol melakukan perlawanan adalah karena PKPU itu dinilai bertentangan dengan UU No 7 Tahun 2017. Salah satu asas hukum mengatakan yakni peraturan perundang-undangan yang lebih rendah tidak boleh bertentangan dengan peraturan perundang-undangan yang lebih tinggi (lex superior derogate legi inferiori) dan PKPU No 20 Tahun 2018 dalam pandangan parpol bahwa KPU sudah terlalu jauh masuk ke dalam dapur parpol dan parpol dapat berhenti berasap karena aturan yang dibuat KPU.(Zennis Helen, Membaca Perlawanan Parpol, Republika, 8 Agustus 2018). Asas inilah yang dipakai oleh MA untuk membatalkan PKPU No 20 Tahun 2018, dan MA tunduk pada asas preferensi, yakni asas penyelesaian konflik antar norma hukum, yang salah satunya adalah lex superior derogat legi inferiori yaitu peraturan perundang-undangan yang lebih tinggi akan melumpuhkan peraturan perundang-undangan yang lebih rendah (Ishom 2017,14).

Setidaknya, ada beberapa problematika dalam pembentukan PKPU No 20 Tahun 2018. Pertama, Undang-Undang No 7 Tahun 2017 tentang Pemilihan Umum (Pemilu) hanya mengatur hal-hal yang umum. Padahal, UU ini adalah bersifat teknis operasional. Ketika sudah berbicara tentang hal-hal yang operasional dan teknis, DPR dan Presiden selalu menyerahkan kepada KPU untuk membuatnya dalam bentuk PKPU. Akibatnya, regulasi mengalami obesitas dan setiap tahapan pemilu ada PKPU-nya dan begitu juga dengan Badan Pengawas Pemilu (Bawaslu). KPU dan Bawaslu bertanding dan berlomba membuat aturan sehingga regulasi pemilu yang di tingkat UU mengalami kodifikasi akan tetapi berjibun dalam bentuk PKPU dan Perbawaslu. Regulasi pemilu semakin sesak dan terlalu gemuk sehingga memusingkan pada tingkat operasional.

Kedua, KPU cenderung membuat PKPU yang bertentangan dengan UU No 7 Tahun 2017 tentang Pemilihan Umum. Hal inilah yang memancing perlawanan parpol. Sekali lagi, KPU melakukan akrobat hukum yang tidak ada cantolannya dalam UU No 7 Tahun 2017 tentang Pemilihan Umum. Padahal, ia harus tunduk pada UU No 7 Tahun 2017 yang menjadi payung hukum pelaksanaan pemilu serentak 2019. Sesungguhnya, niat KPU baik dan elegan, yakni untuk melaksanakan pemilu berintegritas yang tidak hanya penyelenggaranya (baca: KPU, Bawaslu dan Dewan Kehormatan Penyelenggara Pemilu)), melainkan juga pesertanya (baca: parpol yang memeliki otoritas melakukan rekrutmen bakal calon anggota legislative) dan peserta perseorangan (baca: untuk Dewan Perwakilan Daerah (DPD)).

Ketiga, PKPU yang harus dikonsultasikan oleh KPU dengan DPR, dalam relasi pembentukan PKPU (baca: PKPU No 20 Tahun 2018) itu, posisi KPU lemah apabila berhadapan dengan DPR. KPU cenderung menuruti kehendak politik DPR. Sebab, DPR-lah yang melakukan uji kepatutan dan kelayakan KPU. Tidak tertutup kemungkinan, komisioner KPU terpilih sudah mempunyai kepentingan-kepentingan tertentu dengan DPR. Dan ketika keinginan KPU untuk mengatur persyaratan bakal calon anggota legislatif dengan memasukkan persyaratan tidak pernah menjadi narapidana kejahatan seksual terhadap anak, korupsi dan narkoba itu tidak disetujui 
oleh DPR, penyelenggara pemilu itu membuat aturan sendiri yang bertentangan dengan UU No 7 Tahun 2017 Tentang Pemilu.

Keempat, tidak seragamnya latar pendidikan komisioner KPU. Ada yang berlatar belakang sarjana pendidikan, sarjana agama, sarjana teknik, sarjana pertanian dan sarjana peternakan. Padahal, latar pendidikan yang tepat untuk mengurusi kepemiluan adalah sarjana yang berlatar belakang sarjana kepemiluan, sarjana ilmu politik dan sarjana hukum. Beragamnya latar pendidikan ini menyebabkan anggota KPU baik di tingkat nasional, provinsi dan kabupaten/kota kesulitan dalam memahami UU pemilu dan PKPU. Kondisi ini diperparah dengan adanya obesitas regulasi pemilu yang ada di setiap tahapan dan lain sebagainya.

Kelima, adanya obesitas regulasi pemilu dalam pelaksanaan pemilu serentak. KPU membuat aturan dalam bentuk PKPU, sebagai pengawas pemilu, Bawaslu pun membuat lagi aturan untuk mengawasi regulasi yang dibuat KPU, dan DKPP membuat aturan untuk menjaga etik penyelenggara pemilu. Saking banyaknya aturan maka menyulitkan penyelenggara pemilu dalam penerapannya dan seyogianya UU Pemilu dibahas oleh DPR dan Presiden secara mendalam dan detail sehingga tidak ada lagi aturan dalam bentuk PKPU dan Perbawaslu dan peraturan kode etik. Peraturan pelaksanaan dalam bentuk PKPU, Perbawaslu dan Peraturan kode etik DKPP dapat dikurangi bila di UU Pemilu mengatur hal-hal yang detail dan teknis. Tak ada masalah, UU Pemilu dibuat lebih lama dan melalui perdebatan yang mendalam sehingga dapat lebih teknis dan operasional. Bukankah pemilu diselenggarakan secara reguler setiap lima tahun sekali.

\section{Problematika Penegakan Hukum Pemilu (Pelanggaran dan Sengketa)}

Perundang-undangan, termasuk UU No 7 Tahun 2017 tentang Pemilihan Umum adalah kita masih bicara pada tahapan ius constitutum, ia mengkaji secara normatif, aturan-aturan hukum, dan asas-asas hukum yang ada dalam berbagai peraturan perundang-undangan. Objeknya "law in books (Atmadja, 2013:6). Atau ia disebut dengan hukum yang in abtracto (undang-undang), yang salah satu pelajaran yang didapat dari hukum in abstracto adalah hukum tidak pernah lengkap dan tidak pernah sempurna (Manan 2004,V-VI).

Hukum dalam buku dan hukum yang abstrak ini memerlukan hukum yang bersifat ius operatum yang merupakan kajian empiris terhadap hukum, yang fokus pada bagaimana hukum bekerja dalam kenyataan. Objeknya disebut law in action (Atmadja, 2013:6). Kedua jenis hukum diatas saling memerlukan. Ibarat hukum pidana membutuhkan hukum acara pidana. Hukum pidana ditegakkan dengan melaksanakan hukum acara pidana dan lain sebagainya. Ketika dibicarakan tentang problematika penegakan hukum pemilu berarti kita berbicara tentang hukum in concreto dan dan hukum dalam ius operatum, yang mengkaji bagaimana hukum itu bekerja dalam kenyataan.

Penegakan hukum pemilu dalam rangka untuk menghadapi pemilu 2019, Mahkamah Agung (MA) menyiapkan instrumen pendukung dengan mengeluarkan tiga peraturan Mahkamah Agung (Perma), yakni Perma Nomor 4 Tahun 2017 tentang Tata Cara Penyelesaian Pelanggaran Administratif Pemilu, Perma No 5 Tahun 2017 tentang Tata Cara Penyelesaian Sengketa Pemilu di Pengadilan Tata Usaha Negara, Perma Nomor 6 Tahun 2017 tentang Hakim Khusus dalam Sengketa Pemilu di PTUN. Dari empat lingkungan peradilan dibawah MA, perhatian lebih ditujukan kepada TUN. Perkara pemilu juga bisa berujung pada peradilan lain terutama di bawah MA, yaitu 
peradilan umum untuk aspek pidana dan Tata Usaha Negara. (Muhammad Ilham Hasanudin, Republika, 18 September 2018).

Dalam hal ini akan difokuskan kepada pelanggaran administrasi, sengketa pemilu akan dikhususkan pada sengketa proses dan Perselisihan Hasil Pemilihan Umum (PHPU) yang terjadi selama penyelenggaraan pemilu serentak, dengan sistematika dan urutan pembahasan sebagai berikut: pelanggaran pidana pemilu, sengketa proses dan PHPU di Mahkamah Konstitusi (MK). Sebagaimana yang terdapat dalam UU No 7 Tahun 2017 tentang Pemilu, pelanggaran pemilu dibedakan menjadi tiga macam, yakni pelanggaran pidana pemilu, pelanggaran etika pemilu dan pelanggaran administratif pemilu.

Pelanggaran pidana pemilu yang pernah dilakukan penyelidikan oleh Badan Pengawas Pemilu (Bawaslu) adalah adanya dugaan kampanye dini yang dilakukan pasangan calon presiden dan calon wakil presiden nomor urut 01 Joko Widodo- Ma,ruf Amin di media massa. Iklan yang diduga sebagai kampanye dini tersebut muncul di salah satu media cetak nasional. Iklan yang diduga sebagai kampanye dini tayang dalam edisi Rabu (17/10) di salah satu media cetak nasional. Anggota Bawaslu Rahmat Bagja menegaskan pihaknya sedang mencari unsur kampanye dalam iklan tersebut. Ada beberapa unsur yang bisa disebut sebagai sebuah kampanye. Ia mengatakan kampanye di media masa baru dapat dilakukan mulai 21 hari menjelang masa masa tenang kampanye (Republika, 18 Oktober 2018).

Sengketa pemilu dalam UU No 7 Tahun 2017 tentang Pemilihan Umum, dapat dibagi menjadi dua, yaitu sengketa proses dan sengketa hasil. Sengketa proses adalah sengketa antar peserta pemilu dan sengketa peserta pemilu dengan penyelenggara pemilu sebagai akibat dikeluarkannya keputusan Komisi Pemilihan Umum, Komisi Pemilihan Umum Provinsi dan Komisi Pemilihan Umum Kabupaten/kota (https://www.hukumonline.com/klinik/detail/lt5c4533ec18aa6/perbedaan-sengketaproses-dengan-sengketa-hasil-pemilu, diakses Rabu, 16 Oktober 2019, pukul 20.00 WIB) dan pada makalah ini dikhususkan kepada sengketa proses.

Sengketa proses yang terjadi dalam pelaksanaan pemilu serentak 2019 yang menarik perhatian masyarakat luas adalah sengketa antara peserta pemilu (Oesman Sapta Odang (OSO)) sebagai calon anggota DPD yang bersengketa dengan Komisi Pemilihan Umum (KPU). Sengketa ini berawal adanya Surat Keputusan Komisi Pemilihan Umum yang mencoret nama OSO dalam Daftar Calon Tetap (DCT) Anggota DPD. Alasan KPU mencoret nama OSO dalam DCT calon anggota DPD adalah karena OSO merupakan Ketua Umum Partai Hanura dan karena itu OSO pun melawan ke Badan Pengawas Pemilu (Bawaslu) dan tidak puas dengan putusan Bawaslu, ia pun mengajukan gugatan ke Peradilan Tata Usaha Negara (PTUN).

Bila merujuk pada Pasal 470 Ayat (1) UU No 7 Tahun 2017 tentang Pemilu menyebutkan bahwa sengketa proses pemilu di pengadilan tata usaha negara meliputi sengketa yang timbul dalam bidang tata usaha negara pemilu antara calon anggota DPR, DPD, DPRD Provinsi, DPRD Kabupaten/Kota, atau partai politik calon peserta pemilu, atau bakal pasangan calon dengan KPU, KPU Provinsi dan KPU Kabupaten/Kota. Dalam konteks sengketa ini tentu OSO bertindak sebagai Penggugat dan KPU bertindak sebagai Tergugat.

Yang menjadi objek gugatan adalah surat keputusan tentang Penetapan Daftar Calon Tetap (DCT) yang dikeluarkan oleh KPU. Dan putusan Bawaslu terhadap sengketa ini berdasarkan ketentuan Pasal 469 Ayat (1) menyebutkan bahwa " Putusan 
Bawaslu mengenai penyelesaian sengketa proses pemilu merupakan putusan yang bersifat final dan mengikat, kecuali putusan terhadap sengketa proses pemilu yang berkaitan dengan: b) penetapan daftar calon tetap anggota DPR, DPD, DPRD. Dan ayat (2) menyebutkan bahwa "Dalam hal penyelesaian sengketa proses pemilu sebagaimana dimaksud pada ayat (1) huruf a, huruf $b$, huruf $c$ yang dilakukan oleh Bawaslu tidak diterima oleh para pihak, para pihak dapat mengajukan upaya hukum kepada pengadilan tata usaha Negara. Dan ketentuan Pasal 471 Ayat (7) menyebutkan bahwa " putusan pengadilan tata usaha Negara sebagaimana dimaksud pada ayat (6) bersifat final dan mengikat serta tidak dapat diajukan upaya hukum lain. Tiga ketentuan dalam sengketa antara OSO dengan KPU. Setidaknya, telah dua tahapan solusi hukum yang ditempuh, yakni melalui Bawaslu dan yang terakhir melalui peradilan tata usaha negara yang putusannya bersifat final dan tidak dapat dilakukan upaya hukum lain.

Perselisihan Hasil Pemilihan Umum (PHPU) adalah sengketa hasil yang berujung ke MK. Yang menjadi perhatian masyarakat adalah sengketa hasil pemilu Presiden dan Wakil Presiden Joko Widodo- Ma,ruf Amin dengan Prabowo SubiantoSandiaga Salahudddin Uno. Sedangkan, sengketa pileg tidak mendapat perhatian yang luas dari masyarakat karena tertutup oleh sengketa pilpres. Problematika Penegakan Hukum Pemilu (baca: pelanggaran pidana pemilu) adalah sebagai berikut: a) Problematika penegakan hukum pemilu yang berupa pelanggaran pidana pemilu terkait dengan kampanye di media masa diluar jadwal diatas adalah Bawaslu sebagai garda utama yang diberi mandat oleh Undang-Undang No 7 Tahun 2017 tentang Pemilu adalah Bawaslu terkesan lamban dalam menangani pelanggaran pidana pemilu diatas. Padahal, pelanggaran pidana pemilu dilakukan secara terbuka oleh peserta pemilu di media massa yang mempunyai usaha pers. Kelambanan itu dapat dilihat dari terlalu lamanya mencari unsur kampanye dalam iklan tersebut. Padahal, unsur kampanye dalam UU No 7 Tahun 2017 telah jelas. Akibatnya, peserta pemilu tertentu yang telah mengiklankan capres dan cawapres yang ia dukung dan diiklankan di media massa di liar jadwal sama sekali tidak disentuh oleh Bawaslu. Bawaslu terkesan pilih kasih dalam penegakan hukum pelanggaran pidana pemilu. Besarnya pengaruh paslon Joko Widodo karena dia petahana menjadi salah satu penyebab ompongnya pengawasan pemilu dalam melakukan penyelidikan pelanggaran tindak pidana pemilu ini; dan $b$ ) Ketika pelanggaran pidana pemilu sampai ke sentra penegakan hukum terpadu (sentra Gakkumdu) yang terdiri Bawaslu, Kepolisian Negara Republik Indonesia, dan Kejaksaan Agung RI. Sentra Gakkumdu yang difungsikan sebagai forum untuk penyamaan pemahaman terhadap pola penanganan tindak pidana pemilu, ternyata juga tidak efektif. Padahal, tugas mereka sangat penting untuk menilai apakah pelanggaran tersebut masuk kepada domain tindak pidana pemilu atau tidak, karena disana sudah ada penyidik dan penuntut. Jika itu termasuk tindak pidana pemilu maka penyidik kepolisian menyampaikan berkas hasil penyidikannya ke penuntut umum dan apabila sudah lengkap maka penuntut umum melimpahkan berkas perkara ke pengadilan. Dan pengadilan negeri-lah yang bertugas untuk memeriksa, mengadili dan memutus perkara tindak pidana pemilu yang menggunakan Kitab Undang-Undang Hukum Acara Pidana. Akan tetapi tindak pidana pemilu sebagaimana yang telah diuraikan diatas tidak sampai berlanjut ke pengadilan negeri. Netralitas institusi kepolisian dan kejaksaan juga diragukan dalam mengungkap tindak pidana pemilu karena bagaimana pun Kapolri dan Jaksa Agung merupakan lembaga yang berada dibawah otoritas Presiden Joko Widodo sebagai petahana. 
Problematika penegakan hukum pemilu (baca: sengketa proses pemilu) adalah sebagai berikut: a) Putusan sengketa proses antara OSO dengan KPU telah sampai pada putusan PTUN Jakarta dan majelis hakim memerintahkan agar KPU membatalkan, mencabut dan menerbitkan surat keputusan baru atas Surat Keputusan KPU yang mencoret nama OSO dalam Daftar Calon Anggota DPD. Namun, putusan PTUN Jakarta yang bersifat konkrit, individual dan final itu tidak dilaksanakan oleh KPU dan KPU lebih mematuhi putusan MK yang tidak membolehkan calon anggota DPD berasal dari parpol. Padahal, putusan pengadilan tidak boleh tidak harus dilaksanakan oleh KPU RI dan sudah mempunyai kekuatan hukum tetap; b) Ada dua putusan pengadilan yang bertentangan sehingga KPU tidak tahu yang mana yang akan dipatuhi. Padahal, putusan hakim PTUN Jakarta bersifat konkrit, individual dan Final. Konkrit adalah objek yang diputuskan dalam Keputusan Tata Usaha Negara (KTUN) tidak abstrak, tetapi berwujud, tertentu atau dapat ditentukan, individual adalah KTUN tidak ditujukan untuk umum, tetapi tertentu baik alamat maupun hal yang dituju kalau yang dituju itu lebih dari seorang, tiap-tiap nama orang yang terkena putusan itu disebutkan, final adalah KTUN yang dikeluarkan itu sudah definitif dan karenanya dapat menimbulkan akibat hukum ( Harahap 2007, 66). Sesungguhnya putusan peradilan yang bersifat konkrit, individual dan Final yang ditaati oleh KPU, bukan putusan MK. Karena putusan MK itu yang diuji oleh konstitusionalitas UndangUndang, sedangkan putusan hakim PTUN Jakarta yang diuji dan disasar oleh produk hukum yang langsung dikeluarkan KPU; dan c) Sengketa antara OSO melawan KPU. Dapat dipetik empat pelajaran penting, Pertama, putusan PTUN adalah macan ompong, dan bersifat non-eksekutorial. Eksekusinya diserahkan kepada pihak tergugat (baca: KPU), tidak ada instrumen hukum yang dapat memaksa Tergugat (baca: KPU) untuk melaksanakan putusan PTUN Jakarta, Ketiga, yang tidak kalah pentingnya adalah fakta ini menyebabkan orang atau badan hukum malas bersengketa di PTUN, sengketa antara OSO melawan KPU ini telah memberikan ilmu pengetahuan yang sangat berharga kepada kita.

\section{Penutup}

Proses penyusunan UU No 7 Tahun 2017 tentang Pemilihan Umum sangat kental dengan kepentingan politik partai besar dan telah meminggirkan kepentingan politik partai kecil dan substansi UU Pemilu tidak mencerminkan pada upaya perbaikan pemilu di masa mendatang dan hanya mengedepankan kepentingan jangka pendek kekuasaan. UU Pemilu dibuat lebih detail sehingga tidak bertumpuk di tingkat Peraturan KPU yang sering menyulitkan KPU propinsi dan KPU daerah. Kodifikasi pemilu yang telah baik dalam UU No 7 Tahun 2017 ternyata tidak diikuti dengan perbaikan di tingkat PKPU. KPU pun melakukan akrobat hukum dengan menambahnambah persyaratan pencalonan anggota DPR, DPR Provinsi, dan DPRD Kabupaten/Kota yang jelas-jelas bertentangan dengan UU No 7 Tahun 2017 tentang Pemilu sehingga dibatalkan Mahkamah Agung. Penegakan hukum baik di pelanggaran pidana pemilu dan sengketa proses pemilu, penegakannya dilakukan pandang bulu karena tergantung pada posisi seseorang. Apalagi pasangan calon itu petahana, padahal setiap orang harus dipandang sama dihadapan hukum tanpa ada diskriminasi dan KPU tidak tunduk pada putusan pengadilan. Padahal, kekuatan putusan pengadilan sama dengan UU yang harus dilaksanakan dalam sengketa proses di PTUN berkekuatan hukum tetap. 


\section{Daftar Pustaka}

A. Rosyid Al Atok, (2015), Konsep Pembentukan Peraturan Perundang-undangan, Setara Press, Malang.

Bagir Manan, (2004), Hukum Positif Indonesia (Satu Kajian Teoritik), FH UI Press.

Fritz Edwar Siregar, (2018), Bawaslu Menuju Peradilan Pemilu, Themis Publishing.

Siti Hasanah, (2018), Sistem Pemilu dan Kualitas Produk Legislasi di Indonesia, Genta Publishing, Yogyakarta.

I Dewa Gede Atmadja, (2013),Filsafat Hukum Dimensi Tematis \& Historis, Setara Press, Malang.

Moh. Mahfud MD, 2009, Politik Hukum di Indonesia, Rajawali Pers, Jakarta.

Muhammad Ishom, (2017), Legal Drafting, Setara Press.

Susi Dwi Harijanti.2017" Sistem Ketatanegaraan Berdasarkan UUD 1945" Makalah yang dipresentasikan dalam cara Bimbingan Teknis Hukum Acara Mahkamah Konstitusi Bagi Dosen dan Staf Pengajar APPTHI di Cisarua Bogor 16 s/d 20 Juli 2017.

A. Afifuddin, Menjaga Hak Pilih Warga, Republika, 28 Juli 2018.

Muhammad Ilham Hasanudin, Republika, 18 September 2018.

Zennis Helen, Titik Kritis Kohesi Sosial, Republika, 29 Oktober 2018.

Zennis Helen, Membaca Perlawanan Parpol, Republika, 8 Agustus 2018.

Republika, 18 Oktober 2018.

https://republika.co.id/berita/koran/newsupdate/17/01/26/okdeg620-waktu-dan-isukrusial-ruu-pemilu.

https:/www.hukumonline.com/klinik/detail/1t5c4533ec18aa6/perbedaan-sengketaproses-dengan-sengketa-hasil-pemilu. 